\title{
Functions of Windbreaks in the Landscape Ecological Network and Methods of Their Evaluation
}

\author{
Jana Podhrázská 1,2,*(D), Josef Kučera ${ }^{1,2}$, Daniel Doubrava ${ }^{3}$ and Petr Doležal $^{3}$ \\ 1 Department of Applied and Landscape Ecology, Faculty of AgriSciences of Mendel University in Brno, \\ Zemědělská 1, 61300 Brno, Czech Republic; kucera.josef.jr@vumop.cz \\ 2 Department for Land Use Planning Brno, Research Institute for Soil and Water Conservation, Lidická 25/27, \\ 60200 Brno, Czech Republic \\ 3 Agroprojekt PSO, s.r.o., Slavíčkova 1, 60300 Brno, Czech Republic; \\ daniel.doubrava@agroprojektPSO.cz (D.D.); petr.dolezal@agroprojektPSO.cz (P.D.) \\ * Correspondence: podhrazska.jana@vumop.cz; Tel.: +420-54-112-6278
}

check for updates

Citation: Podhrázská, J.; Kučera, J.; Doubrava, D.; Doležal, P. Functions of Windbreaks in the Landscape Ecological Network and Methods of Their Evaluation. Forests 2021, 12, 67. https://doi.org/10.3390/f12010067

Received: 24 November 2020

Accepted: 6 January 2021

Published: 8 January 2021

Publisher's Note: MDPI stays neutral with regard to jurisdictional clai$\mathrm{ms}$ in published maps and institutional affiliations.

Copyright: (C) 2021 by the authors. Licensee MDPI, Basel, Switzerland. This article is an open access article distributed under the terms and conditions of the Creative Commons Attribution (CC BY) license (https:// creativecommons.org/licenses/by/ $4.0 /)$.

\begin{abstract}
Linear elements in the agricultural landscape, particularly windbreaks, reduce the wind speed and improve the microclimate in the protected zone. They offer many direct effects on agricultural production with maximum benefits of ecosystem biodiversity. Despite the indisputable advantages and favourable effects of permanent linear vegetation elements, their representation in the agricultural landscape is not as frequent as it used to be. Moreover, the formerly planted elements do not fulfil their original function due to the overgrowth and neglected maintenance. The optimum spatial and functional organisation of the newly proposed linear elements requires evaluation of the existing linear vegetation, its functional parameters and involvement in the landscape ecological network. Our report presents methods for the evaluation of the linear elements, both from the aspect of their internal structure and species composition (category A) and their involvement in the functional system (category B). The evaluation is based on seven established criteria and results in a point scoring system that reflects the characteristics of the reference criteria. In five selected localities, we tested the linear elements as individuals by the A method and their integrity by the B method of evaluation. In one locality only, the state of windbreaks was assessed as functional; at two localities, they were found as conditionally functional, and at two other localities, the state of the windbreaks was assessed as non-functional. An example of the evaluation of individual windbreaks (category A) is demonstrated in model localities in South Moravia, Czech Republic. The results of the evaluation of the model localities thus point out an unsatisfactory state of the linear elements in the region of South Moravia and the need to accord them increased care and to establish new plantations under professional supervision. Their building can be sped up by using the tools of land consolidation.
\end{abstract}

Keywords: wind erosion; windbreaks; landscape ecological network; land consolidation; method of linear element classification

\section{Introduction}

Vegetation is considered a significant landscape element. Elements of greenery form the landscape scenery and fulfil productive and eco-stabilising functions. Trees and shrubs play an important role in the environment and living conditions of other organisms. Shortterm changes in the ecosystems do not have significant impacts on their life cycle and vitality. However, landscapes modified by human civilisations on all continents have been gradually transformed into enormous agricultural expanses, where the native and natural ecosystems have been reduced to small, isolated areas. The functionality of these ecological systems is often seriously threatened. One of the concepts associated with the preservation and reinforcement of ecological stability is the ecological network (EN), broadly defined as a network of localities that have been interconnected to enhance the protection of 
biological diversity. The basic prerequisite for the preservation of the landscape ecological stability is the existence of landscape elements and segments possessing higher inner ecological stability compared to the surrounding landscape. All EN projects in Europe, from the continental to the national level, are devised to encompass, at least, the basic necessary areas and corridors of the green infrastructure [1]. The structural parts of EN, i.e., the ecologically significant landscape segments, can be classified according to several criteria. According to their function, these elements can be classified as bio-centres, bio corridors and interactive elements. In the Czech Republic, the creation of the concept of EN was initiated in the 1990s [2]. Effective utilisation and design of EN require the knowledge of the morphological characteristics, as well as biological and ecological properties of woody plants [2]. These 'Territorial Systems of Ecological Stability in the Landscape' have been designed according to five basic criteria: diversity of potential natural ecosystems, the spatial relationship of the biome in the landscape, spatial parameters, the current state of the landscape, and socioeconomic limits and intents [3,4]. Such elements also include windbreaks, which fulfil many important functions in the landscape.

Windbreaks can fall into the group of bio corridors or interactive elements. The linear elements in the agricultural landscape, particularly windbreaks, reduce the wind speed and improve the microclimate in the protected zone. They offer many direct effects on agricultural production with maximum benefits of ecosystem biodiversity [5]. The reduction in wind speed in the protected zones has a particular impact on the soil and air temperature, the relationship between plant-water, and the soil moisture [6]. When defining the role of windbreaks in the landscape, the windbreaks are among those parts of the landscape that are collectively designated as 'ecologically important linear segments of the landscape'.

Despite the indisputable advantages and favourable effects of permanent linear vegetation elements, their representation in the agricultural landscape is not as frequent as it used to be. Formerly established windbreaks in the landscape may be considered as parts of agroforestry systems. A number of them can also be found in the territory of the Czech Republic, but in many cases, they are no longer functional because since their planting in the 1950s, they have lacked proper care, and numerous trees have withered. Similarly, in other territories, e.g., in Northern America in the 1960s to 1970s, a large number of windbreaks were removed or died $[7,8]$. This phenomenon was associated with overaged stands, planting of woody species unsuitable for the pedologic and climatic conditions, dying of trees due to diseases and pests, effects of droughts and also, improper management [9]. We may say that a similar phenomenon occurs in the conditions of the Czech Republic. The landscape strongly lacks permanent vegetation, particularly linear elements that adequately regulate land management and form barriers to the winds with erosive effects. A major part of formerly planted elements does not fulfil their original function due to overgrown cover and neglected maintenance $[10,11]$. New plantations are difficult to introduce because of unsettled ownership rights. A certain path to enforcing the application of these so needed multifunctional measures is land consolidation, by which the land plots could be organised in a manner allowing the complex solution to the restoration of effective and optimally spatially situated linear elements using public finances [12,13]. The role of land consolidation in restructuring and remediation of the landscape is mainly perceived in the countries dealing with the consequences of intensive or inappropriate land management that led to the development of erosive processes [14], disturbances in the landscape ecological stability, and growing problems with consequences of climate change. Land consolidation and its effects on landscape management in the European context were discussed by [15-17]. The consequences of the application of land consolidation in China were described in detail by [18].

Land consolidation in the Czech Republic deals with many specific tasks-from the restoration of the cadastral apparatus, new organisation of proprietary land plots to the application of multifunctional measures for preserving sustainable land management and improving the landscape ecological stability $[19,20]$. In the process of land consolidation, windbreaks are understood as a primary anti-erosive measure, but they also 
represent (and should represent) an integrated component of the system of ecological measures in their role of important landscape-forming elements. They can appropriately change the landscape character, make the landscape accessible to its inhabitants and serve as a habitat for flora and fauna [21]. Their position in the ecological network has been assessed in many aspects. The primary aspect of their evaluation is their efficiency to protect against wind erosion. This efficiency is, in part, determined by their outer structure, defined by their height, length, orientation, continuity, width, and cross-section form. It is also determined by their inner structure, which is a function of the amount and distribution of free and filled spaces, surface area, and form of individual vegetation elements [22]. The height is the most important factor determining the extent of protection against the wind. The distance between windbreaks is usually defined by their height. The inner structure of windbreaks was previously described based on their density or porosity [23]. At present, attention is focused on defining their 3D aerodynamic structure [24]. The optical porosity of windbreaks concerning their efficiency against wind erosion was discussed by [25]; these authors have found that the dependence of the wind speed reduction on optical porosity decreases with the distance from the windbreak. Stredová et al. [26] compared various methods of evaluation of the windbreak efficiency based on optical porosity and windbreak height. They recommended taking into account both the height and optical porosity. Kučera et al. [27] concluded that the optical porosity best reflects the effect of one-row windbreaks. In the case of wider windbreaks, parameters for expressing the 3D structure should be developed. In contrast, Tonggui [28] assessed the effects of three types of windbreaks on the regulation of wind erosion concerning their structural diversity, reduction in wind speed and optical porosity in the central part of the Czech Republic. The most significant effect on the wind speed reduction in terms of structural indices was found in the total diversity index and Arten-profile index describing vertical structures, which are recommended, along with the optical porosity, to be evaluated in assessing the windbreak efficiency in controlling wind erosion [28]. Other authors deal with the effect of windbreaks on the surrounding microclimate, finding it favourable for both field crops and the effects on humidity and temperature of the surrounding air and soil $[5,29,30]$. The appearance and function of windbreaks are positively impacted by selecting a mix of conifers and deciduous trees and shrubs [31].

Our study aimed to analyse the state of the existing windbreaks according to the presented methodology, critical evaluation of the results of the used methodology and proposals of measures for updating the methodology so far used for the design and application of the land consolidation.

\section{Materials and Methods}

Our study was focused on creating a system of classification of linear elements according to their state and function to allow the utilisation of the results to objectively evaluate not only the linear elements themselves but also their network in the landscape.

As an initial method of evaluation of the state and efficiency of windbreaks, we selected the methodology of linear element assessment based on classification of the parameters of individual windbreaks-species composition, age of the cover, functional type, and horizontal and vertical parameters (gap frequency) - part A, and on the classification of the system of linear elements-part B. This resulted in a point scoring system based on the characteristics of reference criteria. The scoring scale is given in Table 1. 
Table 1. Point scoring of linear element parameters.

\begin{tabular}{|c|c|c|}
\hline \multicolumn{3}{|c|}{ A. Linear Element Categories } \\
\hline \multicolumn{3}{|c|}{ A 1 spatial parameters (quantitative level), criterion-the type of linear element } \\
\hline A 1.1. & $1-2$ lines of woody plants (shrubs), up to $7 \mathrm{~m}$ wide & 1 \\
\hline A 1.2. & multi-linear $\rightarrow$ over $16 \mathrm{~m}$ wide & 2 \\
\hline A 1.3. & multi-linear $\rightarrow$ up to $15 \mathrm{~m}$ wide & 3 \\
\hline \multicolumn{2}{|r|}{ A 2 parameters of different representation of woody plants and shrub species } & * \\
\hline A 2.1. & representation of basic and supplementary woody plants up to $30 \%$ & 1 \\
\hline A 2.2 . & representation of basic and supplementary woody plants $50-31 \%$ & 2 \\
\hline A 2.3. & representation of basic and supplementary woody plants over $51 \%$ & 3 \\
\hline \multicolumn{2}{|r|}{ A 3 parameters of the horizontal composition of woody plants and shrubs } & ** \\
\hline A 3.1. & gaps in the vegetation (dysfunctionality) exceed $50 \%$ of space & 1 \\
\hline A 3.2. & gaps in the vegetation (dysfunctionality) up to $30 \%$ of space & 2 \\
\hline A 3.3. & gaps in the vegetation (dysfunctionality) up to $10 \%$ of space & 3 \\
\hline \multicolumn{2}{|r|}{ A 4 parameters of the vertical composition of woody plants and shrubs } & ** \\
\hline A 4.1. & functional tree level represented up to $50 \%$ & 1 \\
\hline A 4.2 . & functional tree level represented more than $50 \%$ & 2 \\
\hline A 4.3 . & functional multi-level structure more than $50 \%$ & 3 \\
\hline \multicolumn{3}{|c|}{ B. Classification system of linear elements in the landscape } \\
\hline \multicolumn{2}{|r|}{ B 1 parameters defining the distance of spacing elements in the network } & $* * *$ \\
\hline B 1.1. & elements are not set up in a system & 1 \\
\hline B 1.2. & elements set up in a system that do not correspond to the optimum over $50 \%$ & 2 \\
\hline \multirow[t]{2}{*}{ B 1.3. } & elements are set up in a system up to $30 \%$ optimum & 3 \\
\hline & B 2 parameters of element incorporation into the terrain-geomorphological and climatic bonds & $* * * *$ \\
\hline B 2.1. & more than $50 \%$ of elements are not situated in compliance with the terrain morphology and wind direction & 1 \\
\hline B 2.2. & $31-50 \%$ of elements are suitably incorporated into the terrain complying with the wind direction & 2 \\
\hline B 2.3. & element location is ideal in more than $50 \%$ & 3 \\
\hline \multicolumn{3}{|c|}{ B 3 parameters of landscape-ecological elements with a link to the landscapeinfrastructure and ecological network (EN) } \\
\hline B 3.1. & up to $30 \%$ of elements do not have parameters of EN & 1 \\
\hline B 3.2. & $31-50 \%$ of elements have parameters of EN parameters of EN & 2 \\
\hline B 3.3. & more than $51 \%$ of elements have parameters of EN & 3 \\
\hline
\end{tabular}

* Qualitative level—species composition, the structure of vegetation types, criterion—to what degree the linear element differs from the model, ${ }^{* *}$ Element construction- the functional type of linear element (permeable, semipermeable, non-permeable), ${ }^{* * *}$ Criterion of spacing elements usually in an oblong scheme between 350 and $600 \mathrm{~m}$, side belts in the ideal ratio of 1:4 attaining the maximum ecotone effect, ${ }^{* * * *}$ Wind direction and critical speed needed.

The presented method is based on the instructions in materials used in forestry for the construction of windbreaks:

Individual windbreak parameters (categories A):

- Spatial Parameters.

The evaluation is derived from the rate of variation of windbreak width from optimum. A strip width of $12 \mathrm{~m}$ is considered an optimum. Tolerated parameters are $7-15 \mathrm{~m}$. The height of 12-15 $\mathrm{m}$ is considered functional. To evaluate tree species, they are divided into three categories: basic trees, complementary trees and shrubs. Basic trees are characteristic of the natural conditions and are indispensable for planting. This group can make up 40 to $70 \%$ of the total number of trees. Complementary trees are all other tree species suited to the ecological conditions. They increase overall stand diversity. Their amount should be up to $30 \%$. Shrubs are a specific group whose proportion in windbreaks is irreplaceable. Their recommended share is 20 to $50 \%$.

- The horizontal and vertical arrangement of trees and shrubs, windbreak construction. 
The horizontal functionality of the windbreak is due to the area spacing of the stand (missing or insufficiently grown parts of windbreak). The vertical functionality of the windbreak depends on its density (permeability), which is due to the width of the windbreak, the species composition of the trees and shrubs and their row spacing. Trees of trunk shapes constitute the main level, and in the lower levels are shade-loving or shade-laying shrubs and trees and naturally regenerating treetops. A multi-level structure of windbreaks is optimal. We also considered the age of the trees.

General requirements for arranging linear vegetation elements in landscape structure (Categories B):

- Positioning windbreaks in a direction perpendicular to the prevailing wind directions.

- The location of windbreaks following the morphology of the terrain, including the total length of windbreaks in the territory.

- The distance of each strip according to the susceptibility of the soil to erosion.

The procedure for evaluation of the particular locality was done according to the following algorithm:

1st step: scoring the points according to reference criteria;

2nd step: evaluation of the point scores according to groups A and B;

3rd step: an overall evaluation based on the scoring of groups (Table 2).

Table 2. Scheme of the reference point scoring system for linear element classification.

\begin{tabular}{cccc}
\hline Criteria for Evaluation of the Groups & Points & A & B \\
\hline Functional (recommended) & 3 & $10-12$ & $8-9$ \\
Conditionally functional & 2 & $7-9$ & $5-7$ \\
Mostly nonfunctional & 1 & $4-6$ & $3-4$ \\
\hline
\end{tabular}

The concept of the point scoring system is based on the characteristics of reference criteria.

The examples of functional and nonfunctional windbreaks are presented in Figures 1 and 2 .

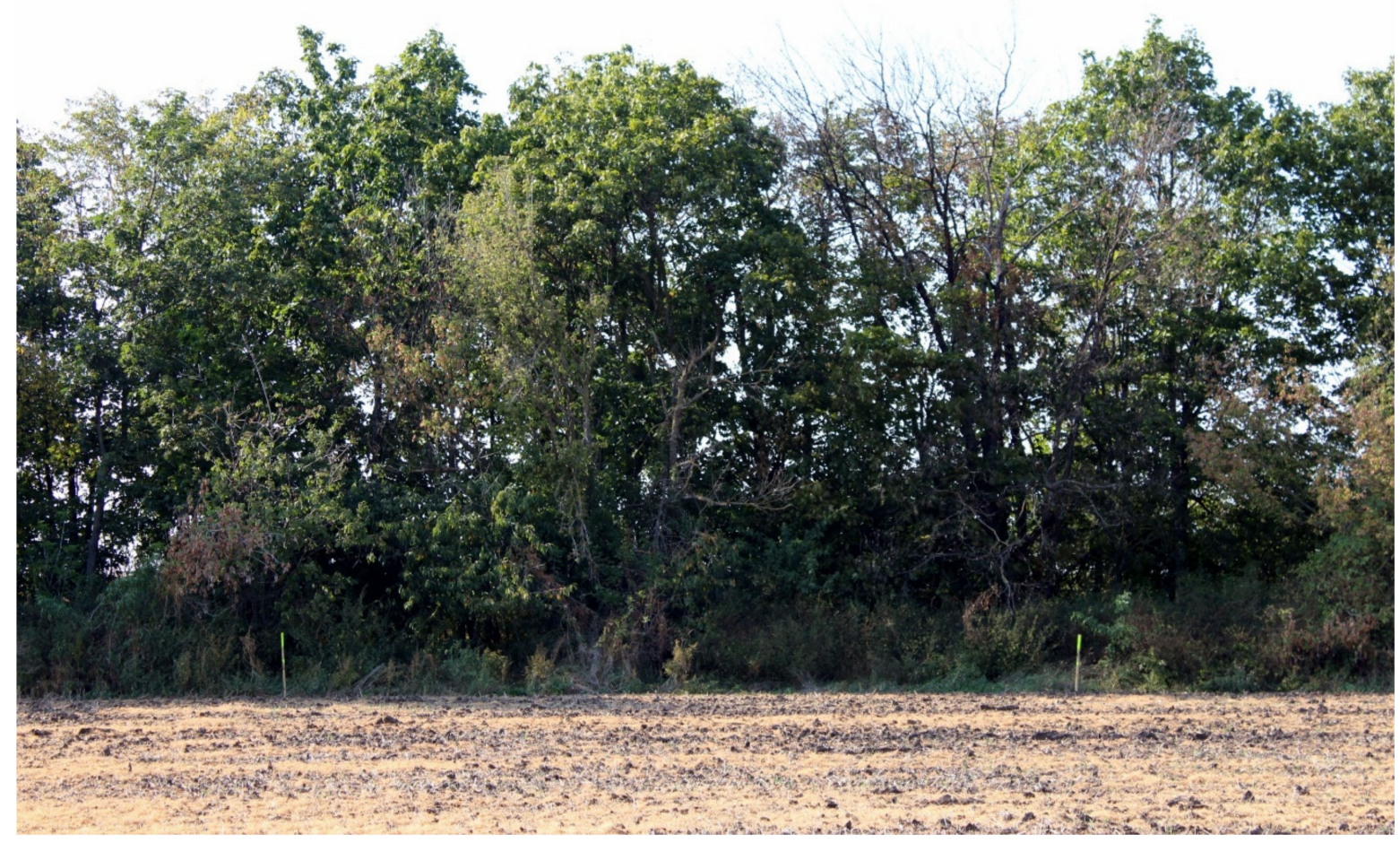

Figure 1. Functional type of windbreaks. 


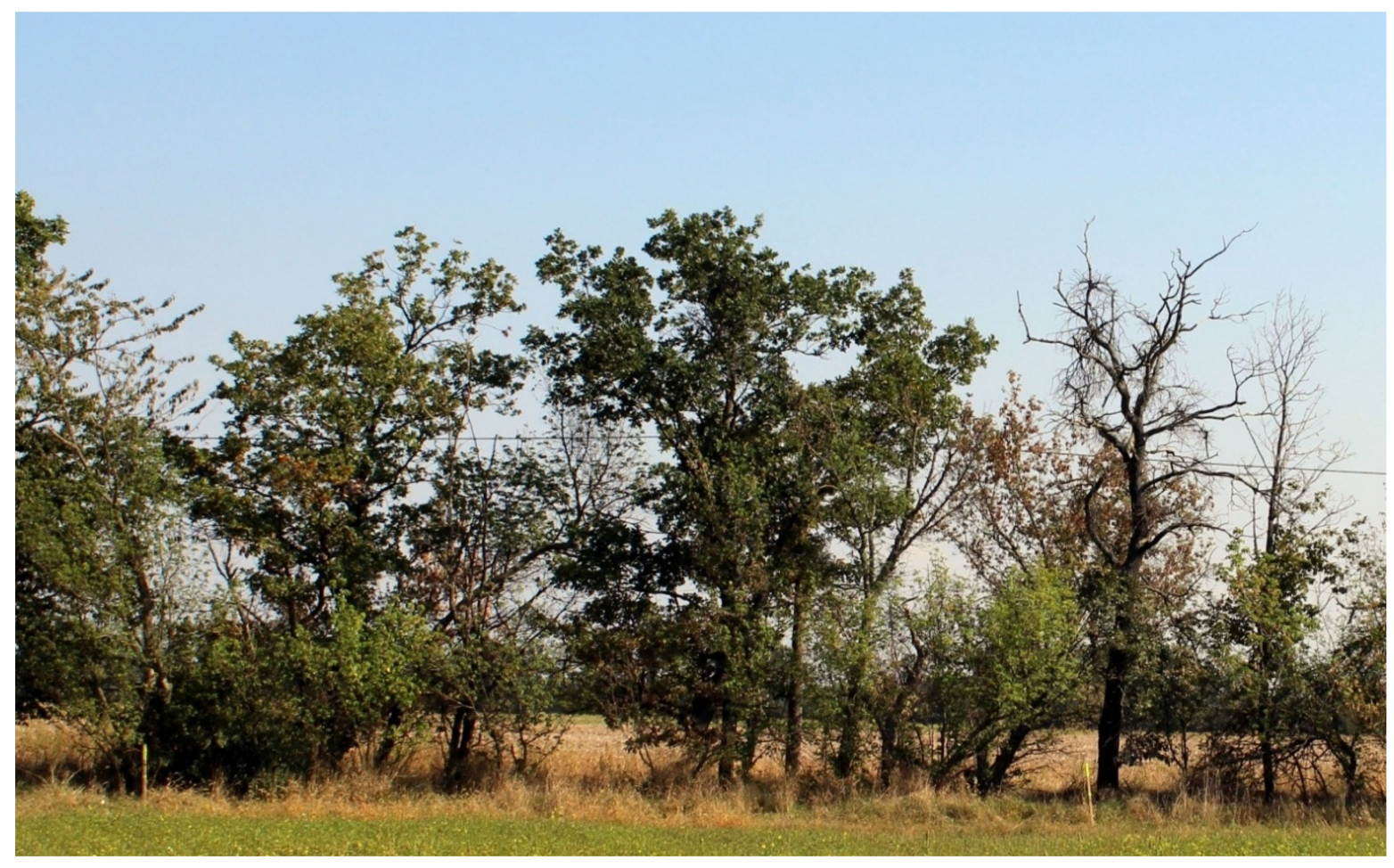

Figure 2. Nonfunctional type of windbreaks.

The selection of the study localities was made according to the map of wind erosion risk in the Czech Republic [14]. We selected localities with a permanent risk of wind erosion, in which we identified vegetation barriers (windbreaks): Bulhary, Tasovice nad Dyjí, Micmanice, Hrušky and Tvrdonice (Figure 3). All these localities are situated in planar areas, with Chernozems easily succumbing to wind with erosive effects in a very warm and dry region. The mean annual temperature fluctuates around $9-10{ }^{\circ} \mathrm{C}$, the mean annual sum of precipitation is $500-600 \mathrm{~mm}$, and the probability of dry vegetation periods is 30 $50 \%$. Here, the role of windbreaks lies not only in the protection against wind erosion but also in the enhancement of the landscape ecological stability because the localities serve intensive agricultural production, with large blocks of arable land and a minimum of natural biotopes.

We performed a detailed inspection of 48 windbreaks in the selected cadastral areas. For all these elements, we assessed the species composition, basic spatial parameters, and state of the cover. The results are expressed as tabular outputs allowing evaluation of the structure of windbreaks according to the selected criteria-category A in Table 1. We also assessed the spatial integrity of the windbreaks concerning their efficiency against wind erosion and their involvement in the landscape ecological network-category $\mathrm{B}$ in Table 1. 


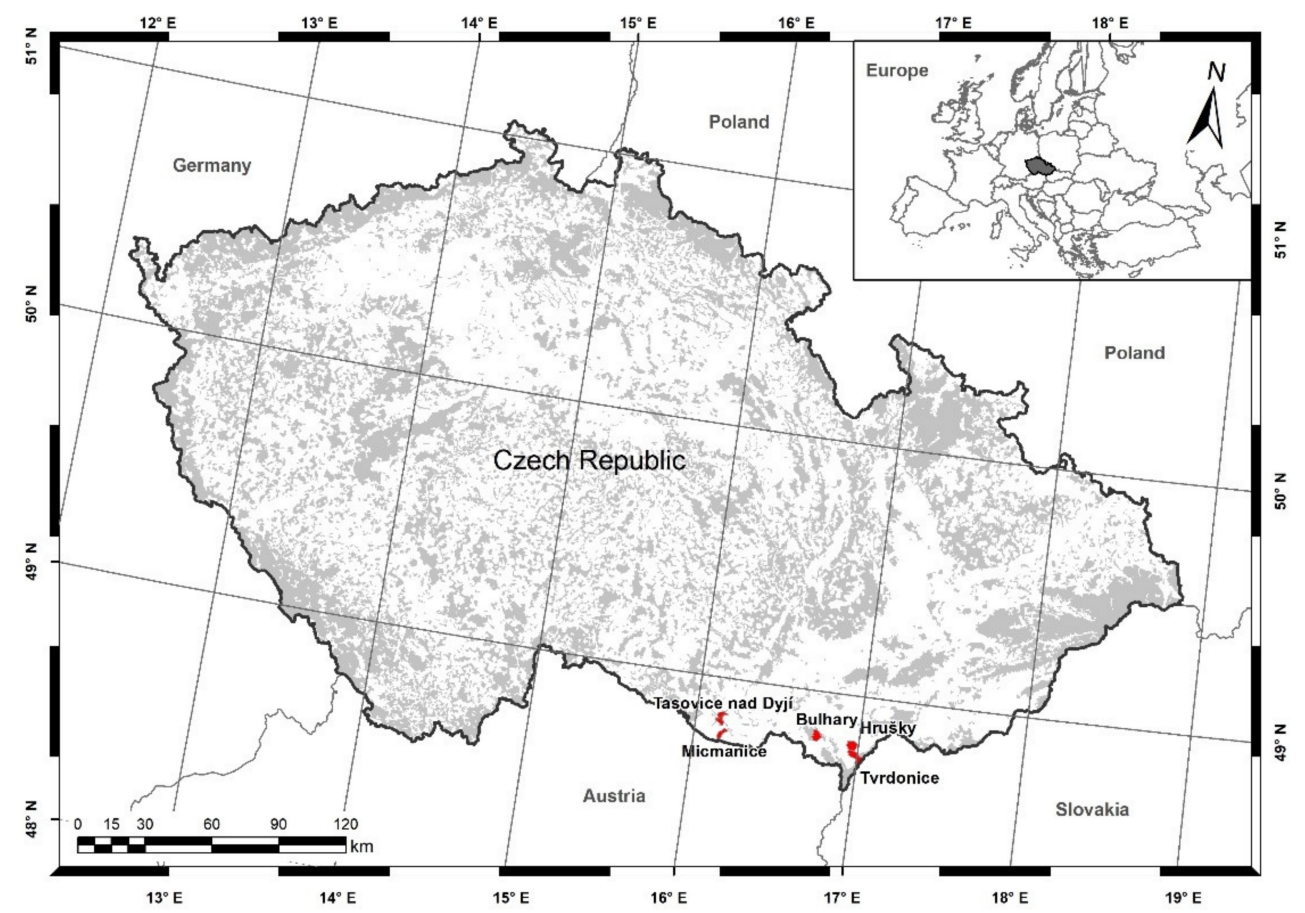

Figure 3. Location of five study localities of the Czech Republic (grey colour indicates forest cover).

\section{Results}

Based on the final evaluation of all selected linear elements according to the spatial parameters and species compositions, we found the following facts:

Thirty-nine point six percent of assessed elements were found functional, $50 \%$ of the elements were conditionally functional, and $10.4 \%$ were considered inadequate. Concerning the general requirements for the organisation of the linear vegetation elements in the landscape structure (category B), the networks of windbreaks in the localities Bulhary and Tvrdonice were found mostly nonfunctional. In the localities of Hrušky and Tasovice, they were assessed as conditionally functional, and only the network of windbreaks in locality Micmanice was considered as fully functional (Table 3).

Table 3. Evaluation of windbreaks according to the category A and category B.

\begin{tabular}{|c|c|c|c|c|c|}
\hline Study Localities & $\begin{array}{c}\text { No. of } \\
\text { Evaluated } \\
\text { Elements }\end{array}$ & $\begin{array}{l}\text { A: No. of } \\
\text { Functional } \\
\text { Elements }\end{array}$ & $\begin{array}{c}\text { A: No. of } \\
\text { Conditionally } \\
\text { Functional Elements }\end{array}$ & $\begin{array}{l}\text { A: No. of Mostly } \\
\text { Nonfunctional } \\
\text { Elements }\end{array}$ & Evaluation of B: \\
\hline Bulhary & 4 & 1 & 3 & 0 & $\begin{array}{c}\text { mostly } \\
\text { nonfunctional (1) }\end{array}$ \\
\hline Hrušky & 1 & 0 & 1 & 0 & $\begin{array}{l}\text { conditionally } \\
\text { functional (2) }\end{array}$ \\
\hline Micmanice & 21 & 11 & 9 & 1 & functional (3) \\
\hline Tasovice & 12 & 0 & 8 & 4 & $\begin{array}{l}\text { conditionally } \\
\text { functional (2) }\end{array}$ \\
\hline Tvrdonice & 10 & 7 & 3 & 0 & $\begin{array}{c}\text { mostly } \\
\text { nonfunctional (1) }\end{array}$ \\
\hline $\begin{array}{l}\text { Total No. of } \\
\text { elements }\end{array}$ & 48 & 19 & 24 & 5 & \\
\hline
\end{tabular}

The individual characteristics of evaluated windbreaks classified to the point system is presented in Table 4 and Figure 2. 
Table 4. Evaluation of windbreaks parameters.

\begin{tabular}{cccccccc}
\hline $\begin{array}{c}\text { Evaluation } \\
\text { in Points/ } \\
\text { Characteristic }\end{array}$ & $\begin{array}{c}\text { Av. Width } \\
(\mathbf{m})\end{array}$ & $\begin{array}{c}\text { Av. Height } \\
(\mathbf{m})\end{array}$ & Av. Age (y) & $\begin{array}{c}\text { Av. Number } \\
\text { of Rows }\end{array}$ & $\begin{array}{c}\text { Av. Number } \\
\text { of Tree Rows }\end{array}$ & $\begin{array}{c}\text { Av. Number of } \\
\text { Shrub Rows }\end{array}$ & $\begin{array}{c}\text { Total } \\
\text { Length (m) }\end{array}$ \\
\hline 1 & 7. & 17.7 & 55.0 & 2.8 & 2.0 & 1.2 & 2826.0 \\
2 & 11.0 & 16.4 & 52.4 & 4.1 & 1.8 & 2.3 & $18,178.0$ \\
3 & 17.5 & 16.8 & 50.3 & 6.7 & 6.1 & 2.9 & $12,304.0$ \\
\hline Total & 13.1 & 16.7 & 51.9 & 5.1 & 3.6 & 2.2 & $33,308.0$ \\
\hline
\end{tabular}

The main functional characteristics were statistically evaluated below (Figure 4):

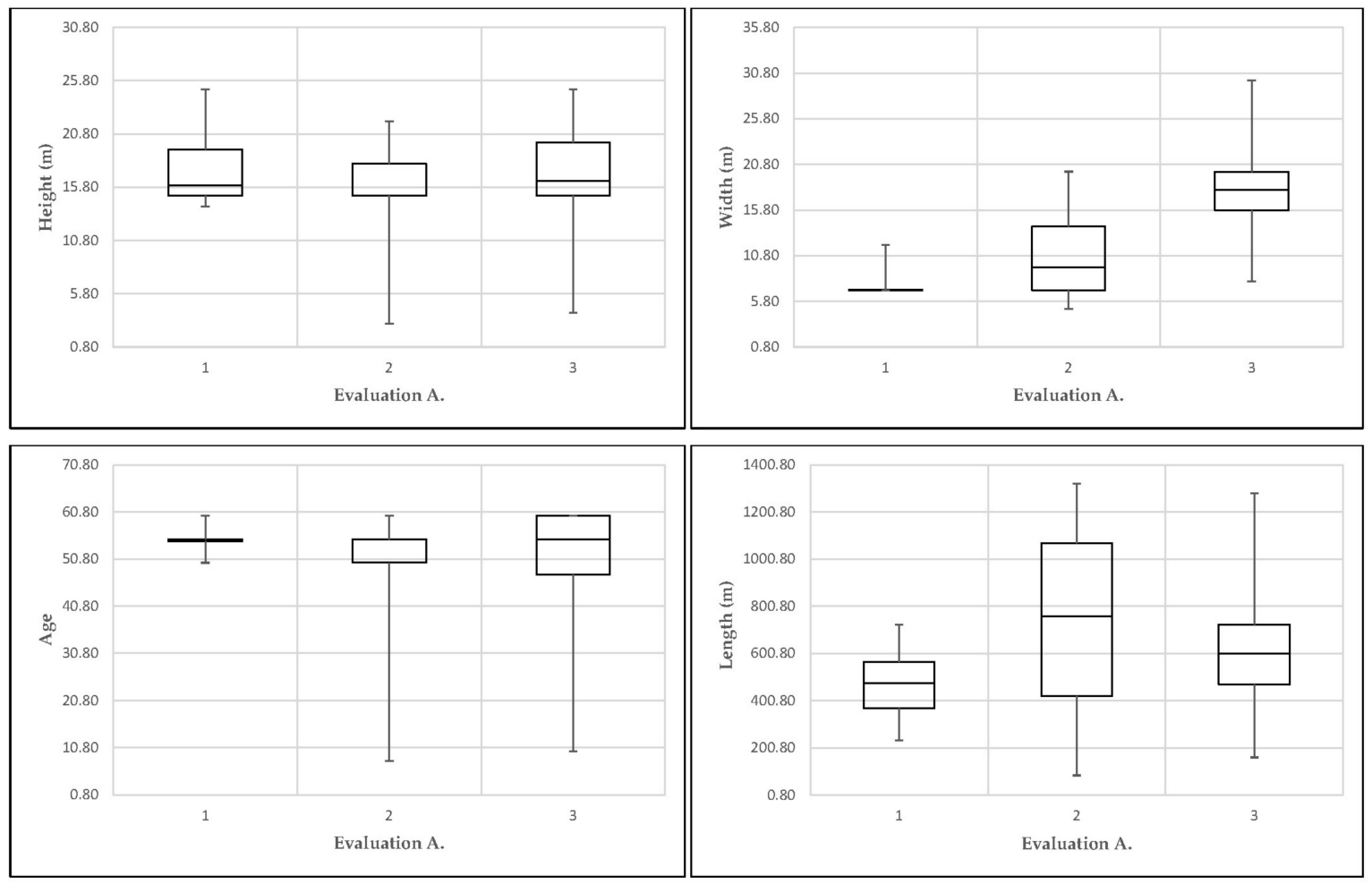

Figure 4. Boxplots of four selected spatial parameters of windbreaks.

Comparing the median values in category 1 of the A rating, the values were height $=16.0 \mathrm{~m}$, width $=7.0 \mathrm{~m}$, age $=55$ years, length $=474.0 \mathrm{~m}$, for category $2:$ height $=18.0 \mathrm{~m}$, width $=9.5 \mathrm{~m}$, age $=55$ years, length $=757.42 \mathrm{~m}$, and for category 3 : height $=16.39 \mathrm{~m}$, width $=18 \mathrm{~m}$, age $=55$ years, length $=600.0 \mathrm{~m}$.

The number of windbreaks classified to point system (mostly nonfunctional, conditionally functional, functional) according to their parameters (A) presents the Table 5.

Table 5. Evaluation of windbreaks parameters.

\begin{tabular}{cccc}
\hline \multirow{2}{*}{ Parameters/Number of Elements } & \multicolumn{3}{c}{ Evaluation in Points } \\
\cline { 2 - 4 } & $\mathbf{1}$ & $\mathbf{2}$ & $\mathbf{3}$ \\
\hline A 1 & 13 & 18 & 17 \\
A 2 & 0 & 32 & 16 \\
A 3 & 0 & 34 & 14 \\
A 4 & 8 & 24 & 16 \\
\hline
\end{tabular}

A basic regression analysis was used to evaluate the relationship between the evaluated windbreak parameters (width, age, height and number of rows in total) and the overall 
point evaluation (1-3) in category A. The confidence interval was calculated for a $95 \%$ confidence level. Selected processed outputs of regression analysis are listed in Table 6:

Table 6. Regression analysis of the relationship of basic wind parameters to the overall point evaluation.

\begin{tabular}{ccccc}
\hline $\begin{array}{c}\text { Analysed Parameters of } \\
\text { Windbreak/Statistic }\end{array}$ & $\begin{array}{c}\text { Correlation } \\
\text { Coefficient }\end{array}$ & $\begin{array}{c}\text { Coefficient of } \\
\text { Determination } \boldsymbol{R}\end{array}$ & $\begin{array}{c}\text { Significance } \\
\boldsymbol{F}\end{array}$ & $\boldsymbol{p}$-Value \\
\hline Width & 0.609 & 0.371 & $3.428 \mathrm{E} \times 10^{-6}$ & $3.428 \times 10^{-6}$ \\
Age & 0.110 & 0.012 & 0.452 & 0.452 \\
Height & 0.026 & 0.001 & 0.860 & 0.860 \\
Number of rows total & 0.595 & 0.355 & 0.001 & 0.001 \\
\hline
\end{tabular}

The analysis shows that the parameters width and number of rows in total have a significant (Correlation coefficient) and statistically significant (Significance $F$ ) influence on the overall evaluation of windbreaks. The correlation coefficient was 0.609 for the height parameter and 0.595 for the number of rows. The value of the significance factor $\mathrm{F}$ was below 0.05 for these parameters, which indicates a statistically clear result. This fact was confirmed by the test of the null hypothesis $(p)$; their value was less than 0.05 . For the other evaluated parameters, the effect on the evaluation was statistically inconclusive. This fact is influenced by the fact that in the evaluated set of windbreaks, older windbreaks were mostly represented (median and mode $=55$ years). The evaluated windbreaks were mostly represented by a height of $15 \mathrm{~m}$ (mode).

Exemplary evaluation of individual windbreaks (category A) is demonstrated on the model localities Micmanice (Figures 5 and 6) and Bulhary (Figures 7 and 8).

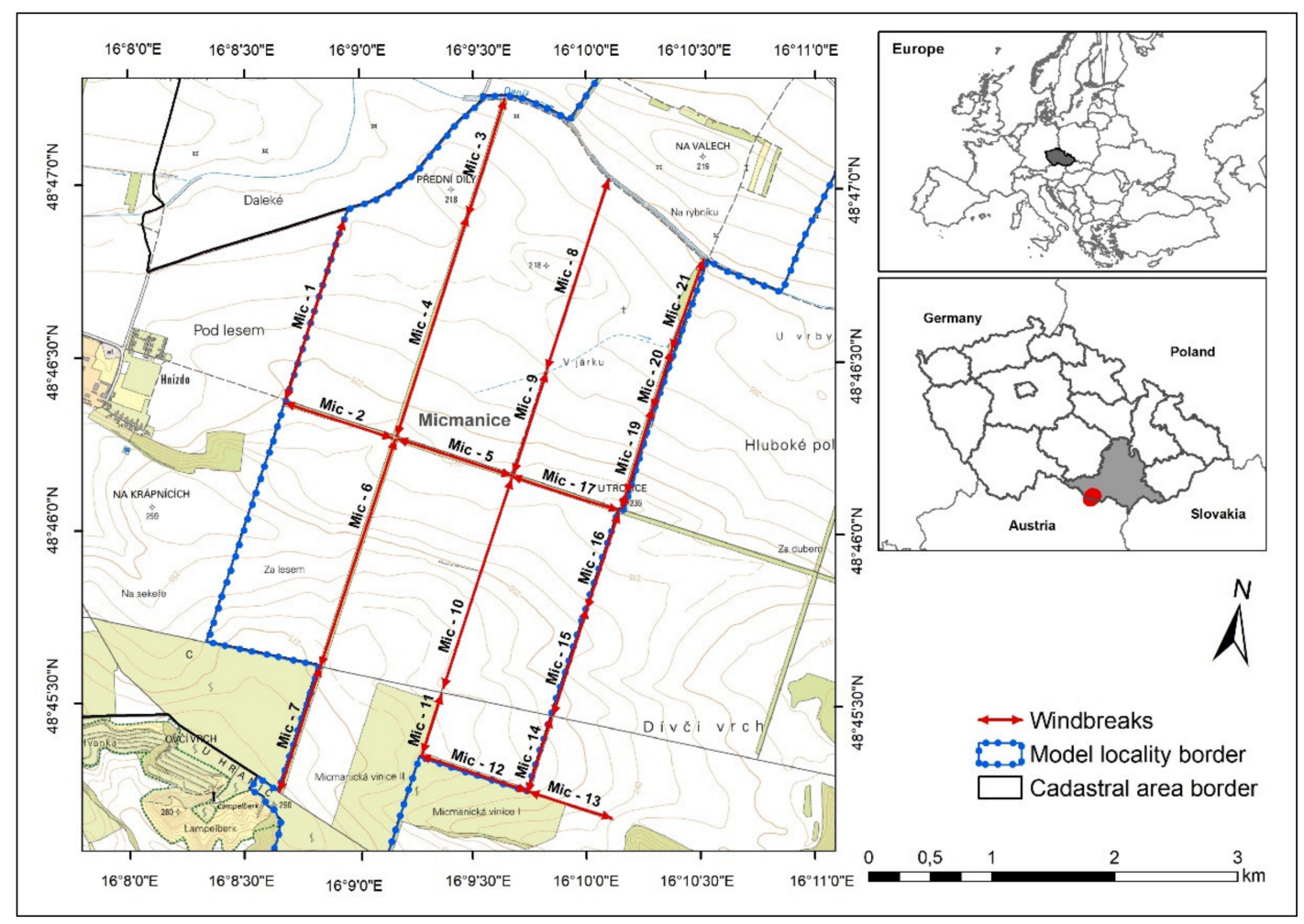

Figure 5. Study locality Micmanice. 


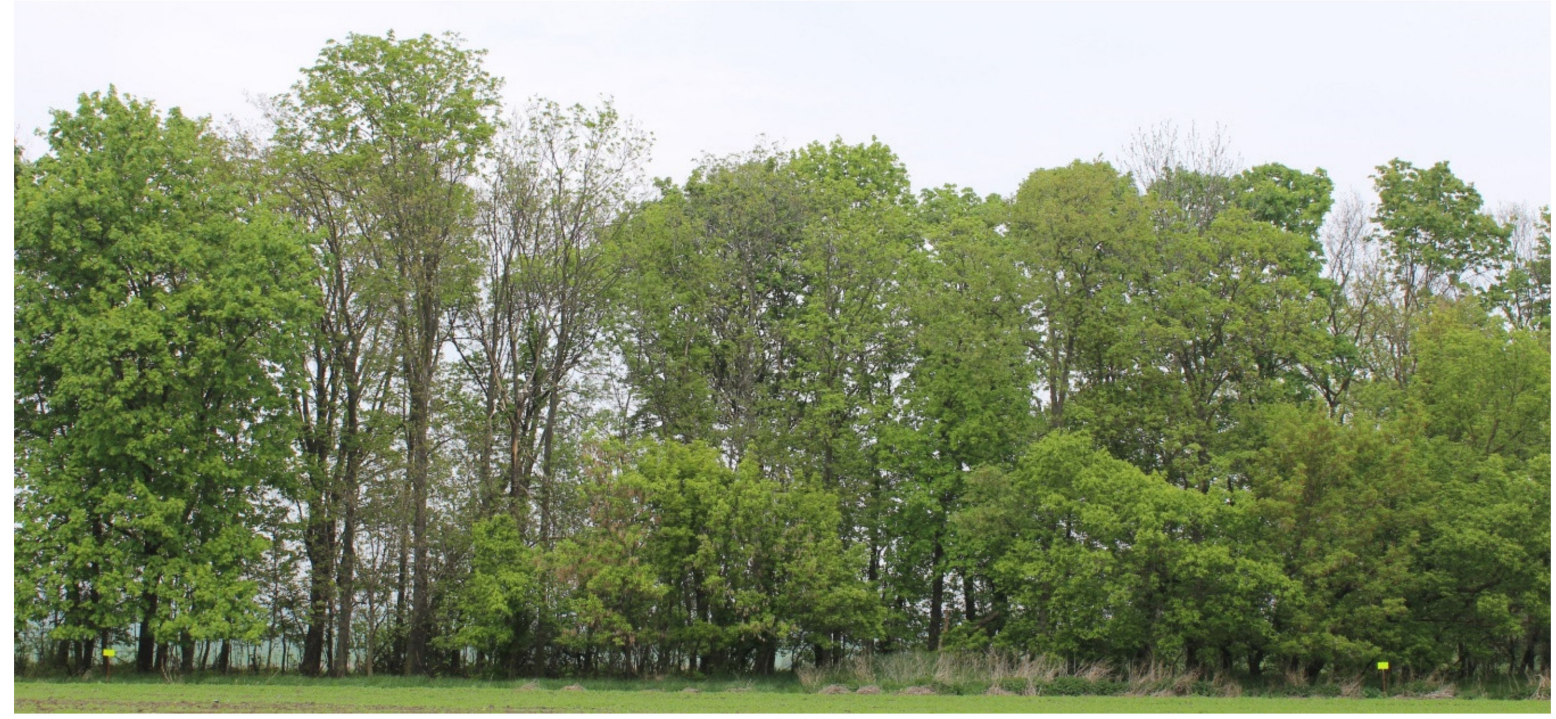

Figure 6. Study locality Micmanice: windbreak 2.

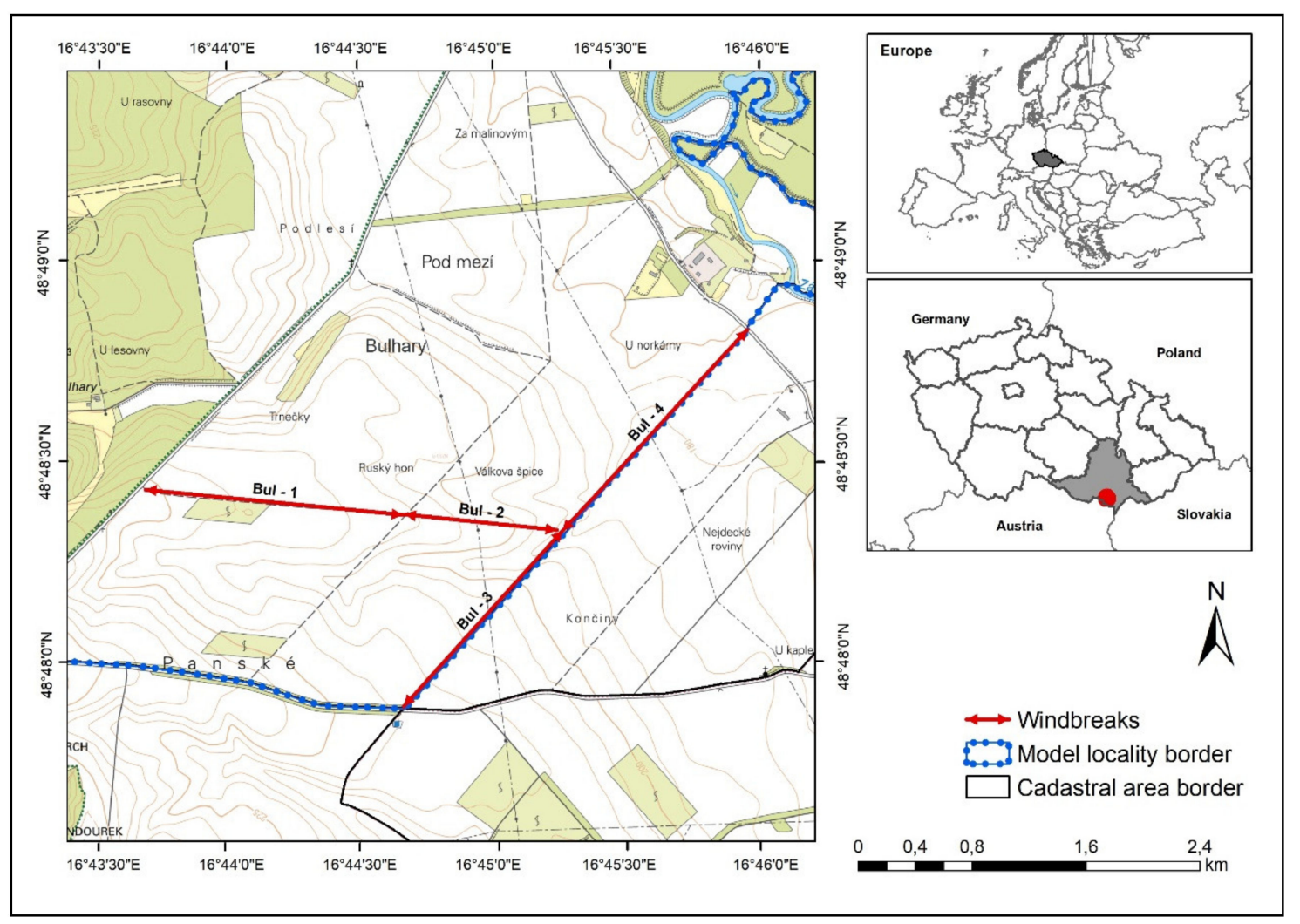

Figure 7. Study locality Bulhary. 


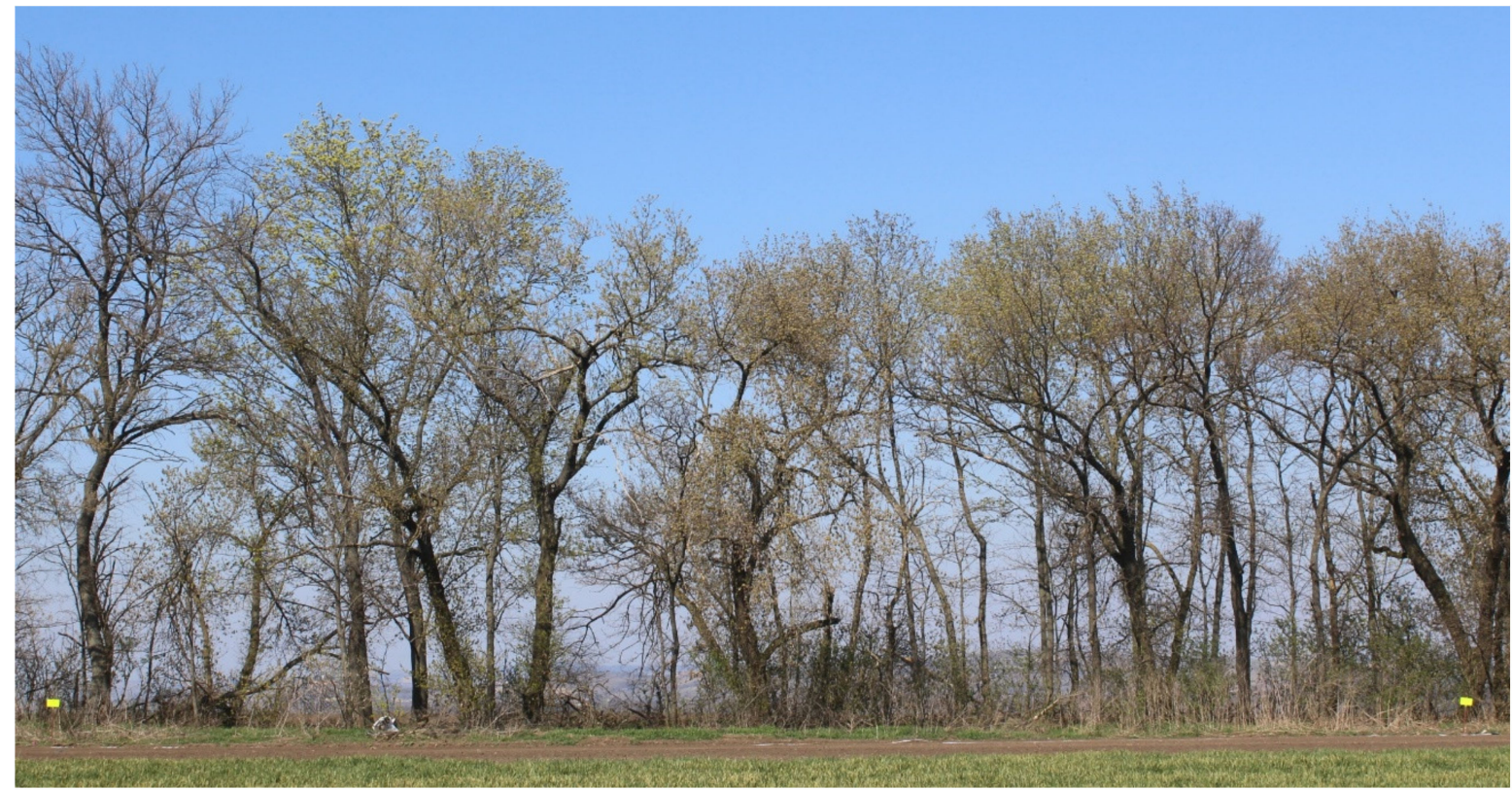

Figure 8. Study locality Bulhary-windbreak 1.

- Study locality Micmanice

These windbreaks (Figure 5) are functional, both as individual elements and as a system. The individual elements are functional mostly conditionally; according to their spatial parameters, some of them are rather nonpermeable, and their species composition, while not optimal, is adequate. The vertical structure of the levels is mostly adequate. Gaps are found only in some places.

From the windbreak network, we selected two representative elements, and their evaluation is given in Tables 7 and 8.

Table 7. Example of the evaluation of two windbreaks in study locality Micmanice.

\begin{tabular}{|c|c|c|c|c|c|c|c|c|c|c|c|}
\hline \multirow{2}{*}{$\begin{array}{c}\text { Element } \\
\text { Designation }\end{array}$} & \multirow{2}{*}{$\begin{array}{l}\text { Length } \\
\text { (m) }\end{array}$} & \multirow{2}{*}{$\begin{array}{l}\text { Width } \\
\text { (m) }\end{array}$} & \multirow{2}{*}{ Age } & \multicolumn{2}{|c|}{$\begin{array}{c}\text { Probable Method of } \\
\text { Planting }\end{array}$} & \multirow{2}{*}{ A 1} & \multirow{2}{*}{ A 2} & \multirow{2}{*}{ A 3} & \multirow{2}{*}{ A 4} & \multirow{2}{*}{ Total } & \multirow{2}{*}{ Evaluation } \\
\hline & & & & $\begin{array}{l}\text { No. of } \\
\text { Rows }\end{array}$ & Distribution & & & & & & \\
\hline Mic-1 & 1011 & 6 & 45 & 3 rows & $\begin{array}{c}1 \text { row of trees } \\
2 \text { rows of shrubs }\end{array}$ & 1 & 2 & 3 & 2 & 8 & 2 \\
\hline Mic-2 & 600 & 20 & 55 & 10 rows & $\begin{array}{c}8 \text { rows of trees } \\
2 \text { rows of shrubs }\end{array}$ & 2 & 3 & 3 & 3 & 11 & 3 \\
\hline
\end{tabular}


Table 8. Example of evaluation of two windbreaks in study locality Micmanice.

\begin{tabular}{|c|c|c|c|c|c|}
\hline Element Designation & Woody Plants Sign. & Woody Plants-Names & Type of Plant & $(\%)$ & Height (m) \\
\hline \multirow[t]{8}{*}{ Mic-1 } & JV & Acer platanoides & Trees & 55 & 15 \\
\hline & JS & Fraxinus excelsior & Trees & 20 & 15 \\
\hline & JVJ & Acer negundo/Negundo aceroides & Trees & 15 & 12 \\
\hline & JLM & Ulmus minor & Trees & 5 & 15 \\
\hline & DB & Quercus robur & Trees & 5 & 15 \\
\hline & Elder & Sambucus nigra & Shrubs & * & * \\
\hline & Caragana & Caragana arborescens & Shrubs & * & * \\
\hline & Birdseed & Ligustrum vulgare & Shrubs & * & * \\
\hline \multirow[t]{8}{*}{ Mic-2 } & JV & Acer platanoides & Trees & 40 & 16 \\
\hline & JS & Fraxinus excelsior & Trees & 30 & 16 \\
\hline & JVJ & Acer negundo/Negundo aceroides & Trees & 20 & 13 \\
\hline & $\mathrm{DB}$ & Quercus robur & Trees & 10 & 16 \\
\hline & Elder & Sambucus nigra & Shrubs & * & * \\
\hline & Caragana & Caragana arborescens & Shrubs & $*$ & * \\
\hline & Birdseed & Ligustrum vulgare & Shrubs & * & * \\
\hline & Blackthorn & Prunus spinose & Shrubs & * & * \\
\hline
\end{tabular}

* Due to high variability in height and percentual representation, was not assessed.

In the figure below (Figure 6), there can be seen the view of windbreak 2 in the late spring.

- Study locality Bulhary

These windbreaks (Figure 7) are functional conditionally as individual elements, not as a system. The individual elements are functional mostly conditionally; according to their spatial parameters, some of them function rather by stopping the wind, with deficiencies in the species composition (about $50 \%$ of poplars and box elders) and in the vertical structure of levels, which is not adequately differentiated. The windbreaks contained gaps due to the disintegration of the cover backbone.

Of the assessed windbreaks, we selected two representative elements, and their classification is given in Tables 9 and 10.

Table 9. Example of the evaluation of two windbreaks in study locality Bulhary.

\begin{tabular}{|c|c|c|c|c|c|c|c|c|c|c|c|}
\hline \multirow{2}{*}{$\begin{array}{l}\text { Element } \\
\text { Designa- } \\
\text { tion }\end{array}$} & \multirow{2}{*}{$\begin{array}{l}\text { Length } \\
\text { (m) }\end{array}$} & \multirow{2}{*}{$\begin{array}{l}\text { Width } \\
\text { (m) }\end{array}$} & \multirow{2}{*}{ Age } & \multicolumn{2}{|c|}{ Probable Method of Planting } & \multirow[t]{2}{*}{ A 1} & \multirow[t]{2}{*}{ A 2} & \multirow[t]{2}{*}{ A 3} & \multirow[t]{2}{*}{ A 4} & \multirow[t]{2}{*}{ Total } & \multirow[t]{2}{*}{ Evaluation } \\
\hline & & & & $\begin{array}{l}\text { No. of } \\
\text { Rows }\end{array}$ & Distribution & & & & & & \\
\hline Bul-1 & 1216 & 14 & 60 & 6 rows & $\begin{array}{c}1 \text { row of poplars } \\
\text { only }\end{array}$ & 3 & 2 & 2 & 1 & 8 & 2 \\
\hline Bul-2 & 708 & 14 & 60 & 6 rows & $\begin{array}{l}4 \text { rows of shrubs } \\
2 \text { rows of trees } \\
4 \text { rows of shrubs }\end{array}$ & 3 & 2 & 2 & 1 & 8 & 2 \\
\hline
\end{tabular}


Table 10. Example of evaluation woody plant representation of two windbreaks in study locality Bulhary.

\begin{tabular}{|c|c|c|c|c|c|}
\hline Element Designation & Woody Plants Sign. & Woody Plants-Names & Type of Plant & $(\%)$ & Height (m) \\
\hline \multirow[t]{9}{*}{ Bul-1 } & $\mathrm{TP}$ & Populus nigra/xcanadensis & Trees & 50 & 22 \\
\hline & DB & Quercus robur & Trees & 25 & 16 \\
\hline & JS & Fraxinus excelsior & Trees & 10 & 18 \\
\hline & LP & Tilia cordata & Trees & 10 & 15 \\
\hline & TR & Prunus avium & Trees & 5 & 12 \\
\hline & Elder & Sambucus nigra & Shrubs & * & $*$ \\
\hline & Caragana & Caragana arborescens & Shrubs & * & * \\
\hline & Amorpha & Amorpha fruticosa & Shrubs & * & * \\
\hline & Wild rose & Rosa canina & Shrubs & * & * \\
\hline \multirow[t]{6}{*}{ Bul-2 } & $\mathrm{TP}$ & Populus nigra/xcanadensis & Trees & 50 & 20 \\
\hline & DB & Quercus robur & Trees & 20 & 16 \\
\hline & JVJ & Acer negundo/Negundo aceroides & Trees & 20 & 14 \\
\hline & JS & Fraxinus excelsior & Trees & 10 & 16 \\
\hline & Amorpha & Amorpha fruticosa & Shrubs & * & * \\
\hline & Caragana & Caragana arborescens & Shrubs & * & * \\
\hline
\end{tabular}

* Due to high variability in height and percentual representation, was not assessed.

In the figure below (Figure 8), the view of windbreak 2 in the spring can be seen.

\section{Discussion}

To plan the investments, work phases and long-term perspective for maintenance and restoration of the existing elements, additional facts must be taken into account. During our study evaluating the windbreak efficiency, we noticed the need to update the applied methodology by adding evaluating criteria not yet included in the classification, in particular:

- Evaluation of the physiological state of the element (backbone woody plants);

- Instead of age (time from planting), evaluation of the age stage and vitality of the cover/woody plants;

- Evaluation of the method of building the element as a base for the decision on the possible way of its restoration;

- Evaluation of the potential of the element and a rough estimation of the possible duration of its adequate functionality.

The majority of the assessed elements lack long-term professional care, which is in accord with the findings of [32]. The used methodology allows the evaluation of the windbreak state not only as anti-erosive protection elements but also of their multifunctional effects in the landscape ecological network. Both [32] and [33] concentrated only on the health status of the stands and their species composition and did not consider their role in the anti-erosive protection; the role in the ecological stability was evaluated only subjectively. Other authors of [34-36] assessed the vegetation elements only from the aspect of species composition and development as well, without evaluating the antierosive function. In contrast, [26,37-39] and others focused on the study of optical porosity of the windbreaks and its effect on the wind speed reduction. Boitani etal. [1] pointed out the need to interconnect all the levels and approaches to the protection of the landscape stability and the difficulties of objective evaluation of the functions and importance of the elements of ecological stability. The method presented in our study is devoted to permanent vegetation linear elements as integral parts of the landscape ecological network in their complex relationship to the environment. It aims to objectively evaluate the windbreaks for the needs of their proper maintenance, restoration and building. Our analysis revealed extensive utilisation of geographically non-native woody plant species in the evaluated windbreaks, as at the time of their building, it was usual, but in the present legislation, this state is not permissible. Some of the used woody plants can be designated as invasive 
species, and in some localities, the authorities of nature preservation recommend their global elimination. The design of necessary guidelines for the selection of woody plants suitable for covers with the required windbreak function thus represents a separate problem. The resistance of the utilised woody plants and cover against gradually increasing extreme climatic effects is another prerequisite for selection and recommendation of adequate species and the method of building vegetation elements using a suitable biotechnique. The approach to building new and complementary linear elements with optimal spatial parameters, including their orientation and density, must be based on the knowledge of the potential and limits of the area and supported by the data obtained using the selected methodology.

\section{Conclusions}

The results of the investigation of the functional properties of windbreaks in category A showed that windbreaks meet the requirements for their heights and gaps to a certain extent-they are mostly classified in grades 2 and 3 . The representation of tree species can also be characterised as moderately satisfactory. In terms of the width of the windbreaks, 13 windbreaks did not reach the optimal width, which is especially true for single-line permeable windbreaks or "unmaintained wide belts". This is mainly due to neglect of line porosities, their overgrowth into arable land or, conversely, the original planting of single-line windbreaks (Table 5). The average height and age of the windbreaks (tree layer) are similar for all windbreaks regardless of their point rating (Table 4). It also indicates the neglect of the stands, the need to clean old trees and plant new ones. The number of rows of trees and shrubs and the width of the windbreak play a major role in evaluating the overall condition of the windbreak and its effectiveness against wind erosion (Table 4).

The evaluation of the windbreak network using category B is, to some extent subjective, necessarily, but it is possible to rely on objective data, such as the prevailing wind direction, data on ecological networks from spatial planning materials and terrain morphology obtained from Digital Model of Relief (DMR).

Our evaluation of windbreaks showed that temporally unified building of the entire system of windbreaks in one locality is the main factor causing the formation of worn-out covers of the same age due to the global disintegration of the backbone woody plants. The considered guidelines for restoration and building of vegetation elements are, therefore, directed to their stepwise renovation, with preserving parts of the elements in the unsuitable state and removing only individual risk woody plants.

Evaluation of both fully grown windbreaks and newly planted vegetation elements show the need to consider all the required functions of the element without favouring only one: the effectiveness of protection against wind erosion.

The issue of windbreaks and their irreplaceable functions in areas susceptible to wind erosion has become the subject of many discussions. In recent years, attention has turned to their importance for soil conservation, attenuation of the impacts of climate extremes, support of extra-productive functions of the landscape, and last but not least, as part of agroforestry systems. The plantation of alleys in fields is one of the forms of agroforestry. In the Czech Republic, it is just at its beginning but represents one of the possibilities to attenuate the impacts of climate change on the agricultural landscape [40]. Besides ecological benefits, trees may also bring economic benefits to the farmers. The planned use of the timber may determine the selection of the woody plant species.

Responsible design and application of measures supporting maintenance and improvement in the landscape stability require not only the knowledge and objective evaluation of the state of particular linear elements—-windbreaks—but their restoration and long-term care based on practical experience and support of scientific findings. Restoration, care and building new linear elements should apply modern approaches to the selection of the species composition, which often reflects the need to react to climate change and restore plantations of traditional endemic woody species typical of the particular station, which, therefore, has more resistant and increases the aesthetic value of the area. Particular 
attention should be paid to the selection of optimal woody plant species having regard to the increasing mean temperature and lack of moisture in some regions.

The methodology presented in this paper was, at first, focused on the function of windbreaks against wind erosion and the protection of the arable land because, in the past, it was the main purpose for planting them. At the second, we thought about their ecosystem services, which will be our important future survey work. Now we propose to evaluate (by the presented methodology) the windbreaks planted in the area endangered by wind erosion in our country. Then we propose to develop a new methodology-how to plant new linear elements and how to rebuild/reconstruct the present ones so that they fulfil both their wind protection functions and the ecosystem services.

In decision-making and projects, the interested parties can complement the existing approaches and methodologies with the additional partial evaluation criteria. This will allow more effective decisions on the urgency of the restoration works and more responsible division into phases considering the possible methods of restoration. All recommendations concerning the species selection, biotechnology and plantation forms should be proposed with the awareness of climate change.

The major obstacle to planting, besides the ignorance of farmers and inequality of the funding conditions, is the management of rented land, which prevails in the Czech Republic. Planting trees represents a long-term investment, and the land plots are often rented, some for few years only. Land consolidation could be an effective tool to support agroforestry and planting linear vegetation. Priorities of the land consolidation in its role of the community serving investment should concentrate on applying such measures that would contribute to facilitating the preservation of natural resources and improving the rural areas particularly. There is no doubt that windbreaks as multifunctional elements in the agricultural landscape represent such measures.

Author Contributions: Methodology, supervision and drafting the paper: J.P., field measurements, statistics, maps and figures: J.K., evaluation of the shelterbelts: D.D. and P.D. All authors have read and agreed to the published version of the manuscript.

Funding: This research has been supported by the projects of the Ministry of Agriculture CR Nos. RO0218 and QK 1710197.

Institutional Review Board Statement: Not applicable.

Informed Consent Statement: Informed consent was obtained from all subjects involved in the study.

Data Availability Statement: The data presented in this study are available on request from the corresponding author. The data are not publicly available due to ongoing research.

Conflicts of Interest: The authors declare no conflict of interest.

\section{References}

1. Boitani, L.; Falcucci, A.; Maiorano, L.; Rondinini, C. Ecological Networks as Conceptual Frameworks or Operational Tools in Conservation. Conserv. Biol. 2007, 21, 1414-1422. [CrossRef] [PubMed]

2. Buček, A.; Lacina, J.; Míchal, I. An ecological network in the Czech Republic. Veronica 1996, 10, 1-45.

3. Buček, A.; Maděra, P.; Úradníček, L. Czech Approach to Implementation of Ecological Network. J. Landsc. Ecol. 2012, 5, 14-28. [CrossRef]

4. Mackovčin, P. A multi-level ecological network in the Czech Republic: Implementating the Territorial System of Ecological Stability. GeoJournal 2000, 51, 211-220. [CrossRef]

5. Brandle, J.R.; Finch, S. How Windbreaks Work. Pap. Nat. Resour. 1991, 121, 1-5.

6. Bilbro, J.D.; Fryear, D.W. Annual herbaceous wind barriers for protecting crops and soils and managing snowfall. Agr. Ecosyst. Environ. 1988, 22/23, 149-161. [CrossRef]

7. Griffith, P. Introduction of the problems, in shelterbelts on the Great Plains. In Proceedings of the Symposium, Denver, CO, USA, 20-22 April 1976; pp. 3-7.

8. Sorenson, C.J.; Marotz, G.A. Changes in shelterbelt mileage statistics over four decades in Kansas. J. Soil Water Conserv. 1977, 32, $276-281$.

9. Fewin, R.J.; Helwig, L. Windbreak renovation in the American great plains. Agric. Ecosyst. Environ. 1988, 22, 571-582. [CrossRef]

10. Podhrázská, J.; Kučera, J.; Středová, H. The Methods of Locating Areas Exposed to Wind Erosion in the South Moravia Region. Acta Univ. Agric. Silvic. Mendel. Brun. 2015, 63, 113-121. [CrossRef] 
11. Lampartová, I.; Schneider, J.; Vyskot, I.; Rajnoch, M.; Litschmann, T. Impact of protective shelterbelt microclimate character-istics. Ecológia (Bratislava) 2015, 34, 101-110. [CrossRef]

12. Sklenicka, P. Applying evaluation criteria for the land consolidation effect to three contrasting study areas in the Czech Republic. Land Use Policy 2006, 23, 502-510. [CrossRef]

13. Sklenicka, P.; Kottová, B.; Šálek, M. Success in preserving historic rural landscapes under various policy measures: Incentives, restrictions or planning? Environ. Sci. Policy 2017, 75, 1-9. [CrossRef]

14. Geoportal SOWAC-GIS. Managing the Risk of Wind Erosion. Available online: https://geoportal.vumop.cz/apps/mapovnik/ vetrna_eroze_index.php (accessed on 18 October 2020).

15. Janečková, P.; Janeček, Š.; Klimešová, J.; Götzenberger, L.; Horník, J.; Lepš, J.; De Bello, F. The plant functional traits that explain species occurrence across fragmented grasslands differ according to patch management, isolation, and wetness. Landsc. Ecol. 2017, 32, 791-805. [CrossRef]

16. Vitikainen, A. An Overview of Land Consolidation in Europe. Nord. J. Surv. Real Estate Res. 2004, 1, $25-44$.

17. Pašakarnis, G.; Maliene, V. Towards sustainable rural development in Central and Eastern Europe: Applying land consoli-dation. Land Use Policy 2010, 27/2, 545-549. [CrossRef]

18. Van Dijk, T. Complications for traditional land consolidation in Central Europe. Geoforum 2007, 38, 505-511. [CrossRef]

19. Ge, X.; Zhu, F.; Yang, Y.; Liu, G.; Chen, F. Probing Influence Factors of Implementation Patterns for Sustainable Land Consolidation: Insights from Seventeen Years of Practice in Jiangsu Province, China. Sustainability 2020, 12, 3576. [CrossRef]

20. Sklenička, P.; Hladík, J.; Střeleček, F.; Kottová, B.; Lososová, J.; Číhal, L.; Šálek, M. Historical, environmental and so-cio-economic driving forces on land ownership fragmentation, the land consolidation effect and the project costs. Agric. Econ. Czech 2009, 55, 571-582. [CrossRef]

21. Podhrázská, J.; Vaishar, A.; Toman, F.; Knotek, J.; Ševelová, M.; Stonawská, K.; Vasylchenko, A.; Karásek, P. Evaluation of Land Consolidation Process by Rural Stakeholders. Eur. Countrys. 2015, 7, 144-155. [CrossRef]

22. Cable, T. Nonagricultural benefits of windbreaks in Kansas. Gt. Plains Res. 1999, 9, 41-53.

23. Brandle, J.; Hodges, L.; Zhou, X. Windbreaks in North American agricultural systems. Agrofor. Syst. 2004, 65-78. [CrossRef]

24. Caborn, M. Shelterbelts and Microclimate; Bulletin 29; Her Majesty Stationery Office Forestry Commission; Department of Forestry, Edinburgh University: London, UK; Edinburgh, UK, 1957; pp. 135-138.

25. Zhou, X.H.; Brandle, J.R.; Mize, C.W.; Takle, E.S. Three-dimensional aerodynamic structure of a tree shelterbelt: Definition, char-acterization and working models. Agrofor. Syst. 2005, 63, 133-147. [CrossRef]

26. Středová, H.; Podhrázská, J.; Litschmann, T.; Středa, T.; Rožnovský, J. Aerodynamic parameters of windbreak based on its optical porosity. Contrib. Geophys. Geod. 2012, 42, 213-226. [CrossRef]

27. Kučera, J.; Podhrázská, J.; Karásek, P.; Papaj, V. The Effect of Windbreak Parameters on the Wind Erosion Risk Assessment in Agricultural Landscape. J. Ecol. Eng. 2020, 21, 150-156. [CrossRef]

28. Tonggui, W.; Peng, Z.; Lei, Z.; Wang, J. Relationships between shelter effects and optical porosity: A meta-analysis for tree wind-breaks. Agric. For. Meteorol. 2018, 259, 75-81.

29. Vacek, Z.; Řeháček, D.; Cukor, J.; Vacek, S.; Khel, T.; Sharma, R.P.; Kučera, J.; Kral, J.; Papaj, V. Windbreak efficiency in agri-cultural landscape of the Central Europe: Multiple approaches to wind erosion control. Environ. Manag. 2018, 62, 942-954. [CrossRef]

30. Hodges, L.; Brandle, J. Windbreaks: An Important Component in a Plasticulture System. HortTechnology 1996, 6, 177-181. [CrossRef]

31. Cleugh, H.A. Effects of windbreaks on airflow, microclimates and crop yields. Agrofor. Syst. 1998, 41, 55-84. [CrossRef]

32. Grala, R.K.; Tyndall, J.C.; Mize, C.W. Impact of field windbreaks on visual appearance of agricultural lands. Agrofor. Syst. 2010, 80, 411-422. [CrossRef]

33. Blažejová, A.; Pastor, M.; Martinik, A. Conditions and Functionality of Windbreaks-A Case Study from Southern Moravia (Czech Republic). Rep. For. Res. (Zpravy Lesnickeho Vyzk.) 2020, 65, 20-27.

34. Jelínek, B.; Úradníček, L. The Survival and Growth Rates of Woody Vegetation in the Man-Made Vracov Biocorridor During the Period of 1993-2007. J. Landsc. Ecol. 2010, 3, 5-15. [CrossRef]

35. Úradníček, L. Evaluation of the woody component development of the model bio corridor. Ecológia (Bratislava) 2004, 23 (Suppl. 1), 351-361.

36. Fukalová, P.; Mašíček, T. Impacts of Intensive Agriculture on Current Rural Landscape-A Case Study for South Moravian Landscape, Czech Republic. Acta Univ. Agric. Silvic. Mendel. Brun. 2018, 66, 1099-1109. [CrossRef]

37. Cornelis, W.M.; Gabriels, D. Optimal windbreak design for wind-erosion control. J. Arid. Environ. 2005, 61, 315-332. [CrossRef]

38. Gonzales, H.B.; Casada, M.E.; Hagen, L.J.; Tatarko, J.; Maghirang, R.G.; Barden, C.J. Porosity and Drag Determination of a Single-Row Vegetative Barrier (Maclura pomifera). Am. Soc. Agric. Biol. Eng. 2018, 61, 641-652. [CrossRef]

39. Ǩeháček, D.; Khel, T.; Kučera, J.; Vopravil, J.; Petera, M. Effect of windbreaks on wind speed reduction and soil protection against wind erosion. Soil Water Res. 2017, 12, 128-135. [CrossRef]

40. Brown, S.E.; Miller, D.C.; Ordonez, P.J.; Baylis, K. Evidence for the impacts of agroforestry on agricultural productivity, ecosystem services, and human well-being in high-income countries: A systematic map protocol. Environ. Évid. 2018, 7, 24. [CrossRef] 